\section{US Congress signals new funds for key science areas}

Last-minute budgetary wrangling in the US Congress may have netted science agencies several hundred million dollars more than they had expected for the fiscal year 2008.

As Nature went to press, the House of Representatives had passed a supplementary budget bill for this financial year. The US\$163-billion bill mainly provides extra money for the war in Iraq, but it also contains some domestic spending, including key research priorities.

It includes an additional $\$ 150$ million for the National Institutes of Health (NIH) and $\$ 62.5$ million each for NASA, the National Science Foundation and the Department of Energy's Office of Science. The absolute amounts are relatively small (the $\mathrm{NIH}$, for instance, is a \$29-billion agency), but are a response to criticisms that funding of the NIH has remained flat for the past five years and that although physical-sciences research was designated a priority, it has not been funded as such during the past two years.

\section{Boost biosafety funding to cut risks, say UK officials}

British labs handling the most dangerous diseases need additional funding to ensure that devastating outbreaks do not ravage the nation, an influential group of politicians has said. The review was triggered by last year's outbreak of foot-and-mouth disease, which was traced to a damaged pipe at the Pirbright laboratory in Surrey, and cost the government $\mathfrak{E 4 7}$ million (US\$92 million).

A report by the House of Commons' science select committee warns of "shortcomings" in Britain's funding of highcontainment facilities, especially in terms of maintenance costs. "This must be rectified to ensure the incident at Pirbright is not repeated," the report says.

The report also warns of a "striking" lack of coordination between the bodies that pay for and run high-containment labs.

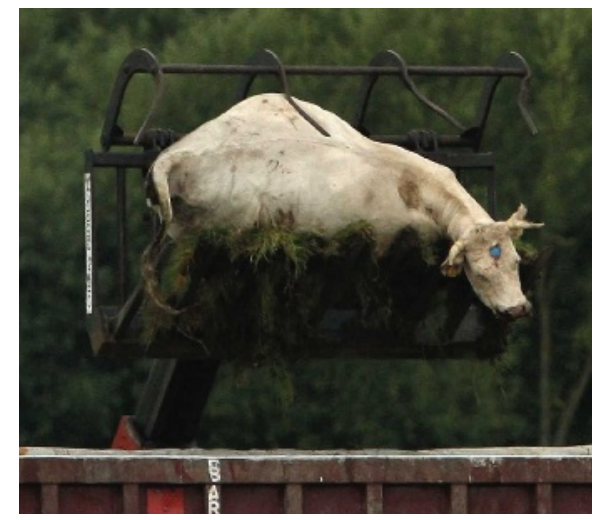

Foot-and-mouth disease devastated British farms.

\title{
Radar and wind farms should coexist, say advisers
}

The US government must do more to make radar systems and wind farms compatible, according to a group of independent scientific consultants.

The spinning blades of wind turbines are known to interfere with defence and weather radar systems. As wind farms have proliferated, both the US and UK governments have sought to limit their growth (see Nature 428, 111; 2004).

But in the United States at least, the government would be better off working to develop regulations and new technologies that can ameliorate the problem, according to the JASONs, a group of academic researchers that advises US defence agencies on a range of issues.

For example, it may be possible to use telemetry data from the farms to lessen the effect, or to replace existing radar systems with more modern units that can handle the noise. The government should invest in a research programme to find the best solution, the group concludes.

In the United States, which is selecting a new site for a high-containment livestock disease lab, a report has warned that an outbreak from such a lab could cost more than $\$ 4$ billion, depending on where the lab is placed. Five sites shortlisted to replace the ageing Plum Island biosecurity lab off Long Island in New York are all on the mainland.

\section{Phoenix digger uncovers ice in Martian soil}

NASA's Phoenix lander watched some bright nuggets, exposed in a trench it had dug near the martian north pole, disappear over the course of four days last week.

That disappearance, mission officials say, means that the material must be made of ice and not the other alternative, salt. The ice sublimated away - that is, turned directly to vapour. "Salt can't do that," says Peter Smith of the University of Arizona in Tucson, principal investigator for the mission.

The lander is now digging other trenches, as well as scooping soil for chemical analysis.

\section{International stem-cell collaborations launched}

California's stem-cell institute has penned two international research agreements, including a pact with Canada that will bring in at least US\$100 million for cancer-related studies.

The California Institute for Regenerative Medicine (CIRM) will form partnerships with a consortium of Canadian research facilities and the state government of Victoria

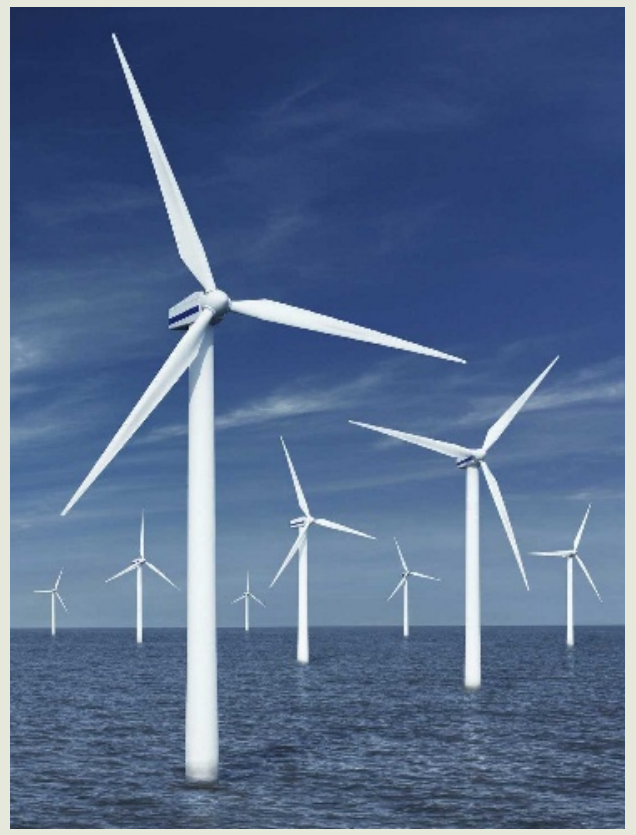

in Australia, officials announced at last week's BIO International Convention in San Diego, California.

CIRM will decide this autumn precisely how much it will contribute to the partnership with the Canadian Cancer Stem Cell Consortium, which involves agencies such as the Canadian Institutes of Health Research in Ontario. Canadian officials say they have committed $\$ 100$ million over three years, with the possibility of expanding to $\$ 250$ million within five years.

Under the Australian agreement, CIRM-funded researchers in California would collaborate with colleagues at institutes in Victoria, such as Monash University - the former home of CIRM president Alan Trounson.

\section{Latest satellite launches to monitor sea level}

Global sea level, as it inches ever higher, has a new eye keeping watch on it from orbit.

On 20 June, the US and French space agencies launched the next-generation ocean topography satellite, the Ocean Surface Topography Mission, or Jason-2. The satellite will continue to monitor seasurface height, a continuous series of measurements that began with the present Jason-1 mission.

Jason-2 is a joint venture of two US agencies (NASA and the National Oceanic and Atmospheric Administration), France's space agency (CNES), and the European satellite agency EUMETSAT.

Jason-1 is still operating; Jason-2 will orbit beneath it during its commissioning phase. 